Acta vet. scand. $1972,13,281-283$.

Brief Communication

\title{
GASES OF EQUINE COITAL EXANTHEMA IN DENMARK
}

A venereal disease usually designated equine coital exanthema (ECE) has been observed in horses all over the world. In a very few cases a virus, claimed to be the causative agent of the disease, has been isolated.

In May 1971 a number of cases of this disease occurred in Denmark in mares covered by 1 certain stallion.

On May 8, 1971, it was reported by a practitioner that 2 mares had developed vulvovaginitis 7 to 9 days after the first mating. When examined clinically on May 11, 1971, both the stallion and the mares were in a late phase of the disease. On the penis of the stallion there were both ulcers and areas of depigmentation, the latter obviously being scars from a previous manifestation of the disease.

The stallion had been imported from Western Germany 1 month before, and up to May 11 he had served 13 mares. After that he was excluded from service until the lesions had healed.

Table 1. Virological examination of material from horses with coital exanthema.

\begin{tabular}{cccc}
\hline Material $^{\star}$ & $\begin{array}{c}\text { Date of } \\
\text { collection }\end{array}$ & $\begin{array}{c}\text { Tubes with CPE/ } \\
\text { tubes inoculated }\end{array}$ & Titer* $^{*}$ \\
\hline Mare 10, vaginal swab & $8-5-71$ & $10 / 10$ & 10 \\
pus I, vulva & $11-5-71$ & $0 / 10$ & 0 \\
pus II, vulva & $11-5-71$ & $2 / 10$ & 0.2 \\
scrapings, vulva & $11-5-71$ & $10 / 10$ & 1 \\
Mare 9, vaginal swab & $8-5-71$ & $10 / 10$ & 1 \\
Stallion, semen * & $8-5-71$ & $10 / 10$ & 30 \\
\hline
\end{tabular}

* Five ml of PBS with $2 \%$ calf serum added to each sample. Titers refer to $50 \%$ tissue culture infective doses per $0.1 \mathrm{ml}$ of this suspension.

* * Collected from vagina of Mare 10, and virus may derive from that animal. 
For virological and serological examinations, the 6th and following passages of a horse testis cell culture were used. During the preceding passages it had been found free from cytopathogenic viruses.

The material examined virologically and the results of the examinations are presented in Table 1. Titration was performed a few days after primary isolation. Material was stored at $-55^{\circ} \mathrm{C}$. CPE appeared within $24 \mathrm{hrs}$. of inoculation.

T a ble 2. Results of neutralization tests and information about the horses concerned.

\begin{tabular}{|c|c|c|c|c|c|c|c|c|c|}
\hline Horse & $\begin{array}{c}\text { Age } \\
\text { in } \\
\text { years }\end{array}$ & $\begin{array}{c}\text { Number of } \\
\text { previous } \\
\text { mating } \\
\text { seasons }\end{array}$ & $\begin{array}{c}\text { Number } \\
\text { of } \\
\text { foals }\end{array}$ & $\begin{array}{c}\text { Dates of } \\
\text { mating } \\
\text { April-May } \\
1971\end{array}$ & $\begin{array}{l}\text { Preg- } \\
\text { nancy } \\
\text { resulted }\end{array}$ & $\begin{array}{l}\text { symp- } \\
\text { toms } \\
\text { of ECE }\end{array}$ & $\begin{array}{c}\text { Scars } \\
\text { after } \\
\text { infection }\end{array}$ & \multicolumn{2}{|c|}{$\begin{array}{c}\text { Neutralization } \\
\text { titer }\end{array}$} \\
\hline Mare 1 & 7 & 3 & 2 & $16 / 4$ & yes & no & no & 10/6-71: & $<1$ \\
\hline Mare 2 & 11 & 7 & 6 & $19.23 .26 / 4$ & yes & no & no & 10/6-71: & $<1$ \\
\hline Mare 3 & 6 & 3 & 3 & $21.24 / 4$ & yes & no & no & 10/6-71: & $<1$ \\
\hline Mare 4 & 4 & 2 & 1 & $25.27 .29 / 4$ & no & no & no & 10/6-71: & $<1$ \\
\hline Mare 5 & 11 & 6 & 4 & $27.30 / 4$ & no & no & no & 10/6-71: & $<1$ \\
\hline Mare 6 & 8 & unknown & unknown & $28 / 4$ & yes & no & no & $\begin{array}{l}\text { 10/6-71: } \\
\text { 10/3-72: }\end{array}$ & $\begin{array}{l}<1 \\
<1\end{array}$ \\
\hline Mare 7 & 7 & 2 & 2 & $1.5 / 5$ & no & yes ${ }^{\star}$ & no & $\begin{array}{l}\text { 10/6-71: } \\
10 / 3-72:\end{array}$ & $\begin{array}{c}16 \\
5.6\end{array}$ \\
\hline Mare 8 & 5 & 2 & 1 & $\begin{array}{l}21.23 .27 / 4 \\
1 / 5\end{array}$ & no & yes & yes & $\begin{array}{l}\text { 11/5-71: } \\
\text { 10/6-71: } \\
\text { 10/3-72: }\end{array}$ & $\begin{array}{l}2.8 \\
2.8 \\
32\end{array}$ \\
\hline Mare 9 & 5 & 1 & 0 & $\begin{array}{l}28.30 / 4 \\
2.4 .7 / 5\end{array}$ & no & yes & yes & $\begin{array}{l}\text { 10/6-71: } \\
10 / 3-72:\end{array}$ & $\begin{array}{l}8 \\
4\end{array}$ \\
\hline Mare 10 & 10 & 6 & 5 & $1.3 .6 / 5$ & no & yes & yes & $\begin{array}{l}\text { 11/5-71: } \\
10 / 6-71: \\
10 / 3-72:\end{array}$ & $\begin{array}{l}5.6 \\
8 \\
2\end{array}$ \\
\hline Mare 11 & 6 & 2 & 2 & $5.8 / 5$ & no & yes & yes & $\begin{array}{l}\text { 10/6-71: } \\
\text { 10/3-72: }\end{array}$ & $\begin{array}{l}5.6 \\
11\end{array}$ \\
\hline Mare 12 & 6 & 3 & 3 & $9 / 5$ & no & yes & yes & $\begin{array}{l}\text { 10/6-71: } \\
11 / 3-72:\end{array}$ & $\begin{array}{l}45 \\
2.8\end{array}$ \\
\hline Mare 13 & 8 & 4 & 4 & $10.11 / 5$ & no & yes & yes & $\begin{array}{l}\text { 10/6-71: } \\
11 / 3-72:\end{array}$ & $\begin{array}{r}8 \\
16\end{array}$ \\
\hline Stallion & 8 & & & & & yes & yes & $\begin{array}{l}\text { 11/5-71: } \\
10 / 6-71: \\
10 / 3-72:\end{array}$ & $\begin{array}{r}45 \\
256 \\
22\end{array}$ \\
\hline
\end{tabular}

* Painful urination during the week following mating was the only symptom observed. 
The stallion and the 13 mares it had covered were examined by the serum neutralization (SN) test. The $50 \%$ end-point titers are given in Table 2 together with information about each horse. One hundred TCID50 of virus and $0.1 \mathrm{ml}$ of serum dilution were used and final readings taken after 5 to 7 days.

From Table 2 it will be seen that 6 mares, served before May 1 , showed no symptoms, while 7 mares served later were all affected. This is confirmed by the neutralization test. The high SN titer as well as the depigmented areas noted on the penis of the stallion on May 11, indicate a previous manifestation of the infection, and most likely it was a recurrent multiplication of virus in this horse which caused the outbreak.

Of the 6 non-infected mares 4 became pregnant - a normal pregnancy rate. In contrast to this it is striking that none of the 7 infected mares became pregnant. Mares 8 and 10 became pregnant after mating with the same stallion in, respectively, July and October, while Mare 9 remained non-pregnant after mating in September. It is worth noting (Table 2) that on the whole the fertility of the 7 infected mares had previously been satisfactory. So it seems reasonable to assume that an infectious mating will generally not result in pregnancy, but that the infection need not influence results of later matings.

In a cross neutralization test with rabbit sera the Danish strain was indistinguishable from a Norwegian strain received from J. Krogsrud, Oslo. According to J. T. Bryans (personal communication) this Norwegian strain was found identical with strains from several other countries.

V. Bitsch

The State Veterinary Serum Laboratory, Copenhagen, Denmark.

(Received April 25, 1972).

Reprints may be requested from: V. Bitsch, State Veterinary Serum Laboratory, Bülowsvej 27, DK-1870 Copenhagen V, Denmark. 